\title{
ACRL award opportunities
}

The deadline for most awards is December 1, 1995

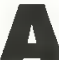

CRL's awards program recognizes special achievements and outstanding publications and fosters professional development in academic and research librarianship. Is someone you know deserving of special recognition for their contributions to academic and research librarianship? Take a moment to nominate these outstanding individuals so they can get the recognition they deserve. Please review the requirements for each award and note those for which you or a colleague are eligible

\section{General submission procedures}

Nominations include documentation (a letter) indicating: 1) your name, address, e-mail, and phone number, plus the name, address, e-mail, and phone number of the person you are nominating; 2) narrative supporting the nomination (keeping in mind the award criteria); 3) a current vita.

Individuals may nominate themselves or others. Unless otherwise indicated send nominations and applications to: (Name of the Award), ACRL, 50 E. Huron St., Chicago, IL 60611

Staff Contact: For a complete list of previous recipients or if you have questions or need help in compiling a nomination contact Jack Briody toll-free at (800) 545-2433, ext. 2516; voice: (312) 280-2516; fax: (312) 280-2520; or e-mail: jack.briody@ala.org.

\section{ACHIEVEMENT/DISTINGUISHED SERVICE}

\section{Academic or Research Librarian of the Year Award}

This award recognizes an individual member of the library profession who is making an outstanding national or international contribution to academic or research librarianship and library development.
Award: $\$ 3,000$ donated by Baker \& Taylor Criteria: Nominees should have demonstrated achievement in such areas as:

1. Service to the organized profession through ACRL and related organizations.

2. Significant and influential research on academic or research library service.

3. Publication of a body of scholarly and/or theoretical writing contributing to academic or research library development.

4. Planning and implementing a library program of such exemplary quality that it has served as a model for others.

Submission procedure: Send eight copies of the nominating package (see general submission procedure above).

Deadline: December 1, 1995

Previous recipients: Joseph Boissé (1995), Irene Hoadley (1994), William A. Moffett (1993), Carla Stoffle (1992), Richard De Gennaro (1991).

\section{Miriam Dudley Instruction Librarian Award}

This award recognizes an individual librarian who has made an especially significant contribution to the advancement of instruction in a college or research library environment. The award honors Miriam Dudley, whose pioneering efforts in the field of bibliographic instruction led to the formation of the ACRL Instruction Section.

Award: $\$ 1,000$ cash donated by Mountainside Publishing Company on behalf of its publication, Research Strategies: A Journal of Library Concepts and Instruction. The award is administered by the Instruction Section of ACRL.

Criteria: Nominees should have achieved distinction in one or more of the following areas:

1. Planning and implementation of an academic instruction program in a library environment that has served as a model for other programs nationally or regionally.

2. Production of a body of research and publication that has a demonstrable impact on the concepts and methods of teaching and information-seeking strategies in a college or research institution. 
3. Sustained participation in organizations, at the national or regional level, devoted to the promotion and enhancement of academic instruction in a library environment.

4. Promotion, development, and integration of education for instruction in ALA-accredited library schools or professional continuing education programs that have served as models for other courses and programs.

Submission procedure: Send nominating package (see general submission procedure above)

to: Katherine Branch, Dudley Award Jury Chair, 111 Smithwood Ave., Catonsville, MD 21228; (410) 541-2213. Call her if you have questions or need help compiling the nomination.

Deadline: December 1, 1995.

Previous recipients: Lizabeth (Betsy) Wilson (1995), Cerise Oberman (1994), Hannelore Rader (1993), Betsy K. Baker (1992), Carla Stoffle (1991).

\section{Hugh C. Atkinson Memorial Award}

This award honors the life and accomplishments of Hugh C. Atkinson, one of the major innovators in modern librarianship, and recognizes outstanding achievement (including risk-taking) by academic librarians that has contributed significantly to improvements in the area of library automation, library management, and/or library development or research.

Award: $\$ 2,000$ cash and a citation. This award is funded by an endowment created by divisional, individual, and vendor contributions given in memory of Hugh C. Atkinson. Additional funds are sought to bring the endowment to at least $\$ 100,000$. Send your tax-deductible contributions to: Hugh Atkinson Memorial Award, ACRL/ALA, 50 E. Huron Street, Chicago, IL 60611. The award is jointly spon- sored by the ACRL, the Association for Library Collections and Technical Services (ALCTS), the Library Administration and Management Association (LAMA), and the Library and Information Technology Association (LITA), four divisions of the American Library Association.

Eligibility: The nominee must be a librarian employed in a university, college, or community college library in the year prior to application for the award and must have a minimum of five years of professional experience in an

academic library.

Criteria: Nominees must have demonstrated achievement (including risk-taking) that has contributed significantly to improvements in the area of library automation, library management, and/or library development or research.

Submission procedure: Send five copies of the nominating package (see general submission procedures on page 563 ).

Deadline: December 1, 1995.

Previous recipients: Nancy L. Eaton (1995), Dorothy Gregor (1994), Richard De Gennaro (1993), Miriam Drake (1992).

\section{EBSCO Community College Learning Re- sources/Library Achievement Awards}

These two annual awards recognize significant achievement in the areas of: 1) programs and 2) leadership.

Award: $\$ 500$ cash for each award plus citations for each award winner are donated by EBSCO Subscription Services.

Eligibility: Individuals or groups from twoyear institutions, as well as the two-year institutions themselves, are eligible to receive awards.

Criteria: Nominees for the program award should demonstrate significant achievement in 
development of a unique and innovative learning resources/library program. Nominees for the leadership award should demonstrate significant achievement in advocacy of learning resources/library programs or services or leadership in professional organizations that are associated with the mission of community, junior, or technical colleges.

Submission procedure: Nominations should consist of the application form (available from the chair), a narrative letter describing achievements, and any supporting attachments. Send four copies of the nominations to: Award Jury Chair, Charles Peguese, Assistant Dean of Instruction Resources, Harrisburg Area Community College, One HACC Drive, Harrisburg, PA 17110-2999.

Deadline: December 1, 1995.

Previous recipients: Leadership or Community Service: W. Lee Hisle (1995), Imogene L. Book (1994); Gloria Terwilliger (1993). Program Development: Derrie B. Roark (1995), Ed Rivenburgh (1994); Lois Marriott (1993).

\section{ACRL/EBSS Distinguished Education and Behavioral Sciences Librarian Award}

This award honors a distinguished academic librarian who has made an outstanding contribution as an education and/or behavioral sciences librarian through accomplishments and service to the profession.

Awarct A citation presented by the EBSS Award Committee.

Criteria: Nominees should have demonstrated achievements in some of the following areas:

1. Service to the organized profession through ACRL/EBSS and related organizations;

2. Significant academic library service in the areas of education and/or behavioral sciences;

3. Significant research and publication in areas of academic library services in education and/or behavioral sciences;

4. Planning and implementation of academic library programs in education and/or behavioral sciences disciplines of such exemplary quality that they could serve as a model for others.

Submission Procedure. Send ten copies of the award nomination form to: Laurene $E$. Zaporozhetz, Louisiana State University in Shreveport, Noel Memorial Library, One University Place, Shreveport, LA 71115. For questions or to request a copy of the form call Zaporozhetz at (318) 798-4131.

Deadline December 1, 1995.

\section{Marta Lange/CQ Award}

This annual award recognizes an academic or law librarian who, through research, other creative activity, or service to the profession, makes distinguished contributions to bibliography and information service in law or political science. This award honors Marta Lange, 1990/91 Law and Political Science Section (LPSS) Chair, whose exceptional talents as a leader were enhanced by a wonderful collegial spirit. Her bright career, cut short in a fatal automobile accident in 1992, was an inspiration to others and a model of professional service.

Award: $\$ 1,000$ and a plaque donated by Congressional Quarterly, Inc. The jury is the LPSS Marta Lange/CQ Award Committee.

Criteria: Nominees should have achieved distinction in one or more of the following areas:

1. Planning and implementing a model bibliography/information services program in a law or political science library.

2. History of contributions to the field through research, publications and other activities displaying active participation in the advancement of law/political science librarianship.

3. Service to the profession through ACRL or related regional and national organizations

4. Promotion or development of an education program for law and political science librarianship that has served as a model for other courses and programs.

Submission Procedure: Nominations should include: 1) a letter of nomination including your name, address and phone number as well as the name and address of the nominee; 2) narrative supporting the nomination; and 3) a current vita.

Individuals may nominate themselves or others. Send 5 copies to the LPSS Marta Lange/CQ Award Committee chair: Ronald Heckart, IGS Library, 109 Moses Hall $\# 2370$, University of California, Berkeley, CA 94720-2370. If you have any questions, call Heckart at (510) 643-6445.

Deadline: December 1, 1995

\section{Instruction Section Innovation in Instruction Award}

This annual award recognizes and honors librarians who have developed and implemented innovative approaches to instruction at their respective institutions.

Award: A citation presented by the Instruction Section Awards Committee. 
Criteria: Recipients must have implemented their ideas in an academic or research library. The emphasis of this award is on creativity and innovation.

Eligibility: There are no restrictions as to the size of the instructional effort, academic discipline, target audience, or techniques employed. Recipients must have implemented their ideas in 1994 or 1995 for the award to be presented in 1996.

Submission Procedure: Nominations (letter and supporting documentation) should be submitted to the chair of the IS Awards Committee, Robert F. Rose, Rod Library, University of Northern Iowa, Cedar Falls, IA 50613. For further questions or information, contact the chair at (319) 273-2737 or at Robert.Rose@uni.edu.

Deadline: December 1, 1995

\section{PROFESSIONAL DEVELOPMENT AND RESEARCH \\ Doctoral Dissertation Fellowship}

This award fosters research in academic librarianship by encouraging and assisting cloctoral students in the field with their dissertation research.

Award: $\$ 1,000$ cash and citation donated by the Institute for Scientific Information.

Eligibility: The recipient of the fellowship must meet the following qualifications:

1. Be an active doctoral student in the academic librarianship area in a degree-granting institution.

2. Have completed all coursework.

3. Have had a dissertation proposal accepted by the institution.

4. A recipient of the fellowship may not receive it a second time.

5. Applicant need not be an ACRL member.

Criteria: The proposal will be judged primarily on merit with emphasis on the following:

1. Potential significance of the research to the field of academic librarianship. (No attempt will be made to define academic librarianship but the subject should be consistent with topics usually published in College E Research L $i$ braries or presented at ACRL meetings.)

2. Validity of the methodology and proposed methods of analysis.

3. Originality and creativity.

4. Clarity and completeness of the proposal.

5. Presentation of a convincing plan for completion in a reasonable amount of time.

6 . Evidence of a continuing interest in scholarship such as a previous publication record.
Submission procedure: Qualified students who wish to be considered for the fellowship may apply by submitting a brief (ten pages or less double-spaced) proposal that includes the following:

1. Description of the research, including significance and methodology.

2. Schedule for completion.

3. Budget and budget justification for items for which support is sought. (Must be items for which no other support is available.) Examples of acceptable budget items are printing, computer time, fees to subjects, statistical consulting, photography, artwork, typing, and professional travel.

4. Name of dissertation advisor and committee members.

5. Cover letter from dissertation advisor endorsing the proposal.

An up-to-date curriculum vitae should accompany the proposal. Because of limits imposed by timing considerations, applications may be made for research under way, e.g., a student who begins research in the fall may apply for support for expenses incurred from the fall until the time the award is made.

Send eight copies of the nominating package (see general submission procedures on page 563).

Deadline: December 1, 1995.

\section{Martinus Nijhoff International West European Specialist Study Grant}

This grant supports research on Western European studies, librarianship, or the book trade.

Award: A maximum of 10,000 Dutch guilders (or U.S. dollar equivalent) donated by Martinus Nijhoff International, a subscription agent and book dealer with headquarters in The Netherlands. This study grant covers air travel to and from Europe, transportation in Europe, and lodging and board for no more than 14 consecutive days. Funds may not be used for salaries, research-related supplies, publication costs, conference fees, or equipment purchases.

Criteria: The primary criterion for awarding the grant is the significance and utility of the proposed project as a contribution to the study of the acquisition, organization, or use of library materials from or relating to Western Europe. Current or historical subjects may be treated. The award jury will review proposals with the following in mind: 


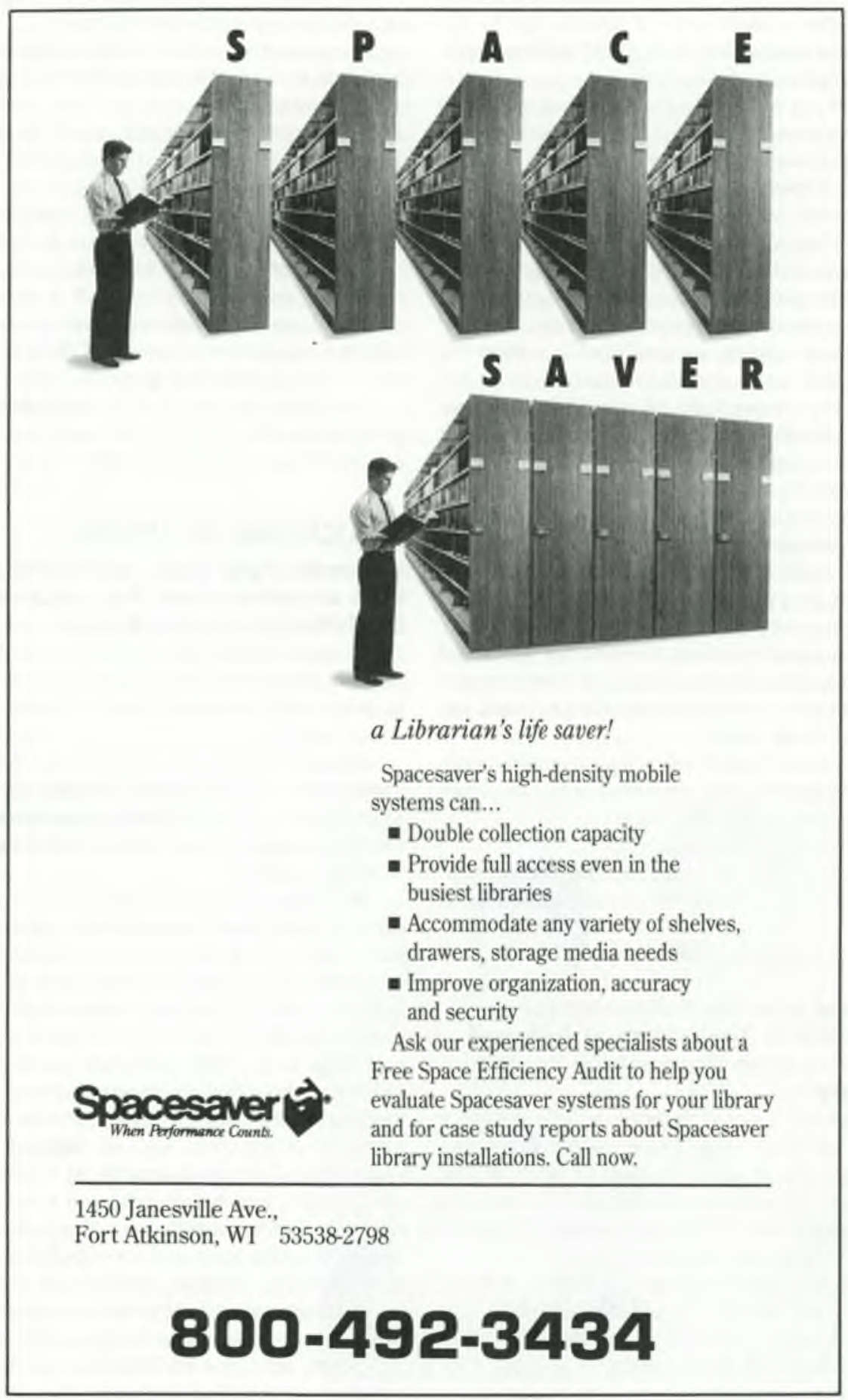


1. What is the work to be accomplished? The proposal should be as explicit as possible about the current state of knowledge in the area and what will be achieved by the successful completion of the study.

2. What is the need for and value of the proposed research? The proposal should provide persuasive evidence that the study is of practical use or scholarly value to the wider community served by the grant.

3. What is the methodology for carrying out the proposed work? The research design should be as specific as possible and demonstrate why the European component is essential.

4. Is the work accomplishable within the time frame proposed? If the study extends beyond the 14-day limit of the grant, the proposal should specify how the additional work will be completed and funded.

5. Are the applicant's qualifications sufficient to carry out the study?

Submission procedure: Send six (6) copies of the application, which includes:

1. A proposal, five (5) pages or less, typed double-spaced.

2. A tentative travel itinerary not to exceed 14 days, including the proposed countries and institutions to be visited and the preferred period of study/travel.

3. A travel budget, including estimated roundtrip coach airfare, transportation in Europe, lodging expenses, and meal costs.

4. A current curriculum vitae.

Send six copies of the nominating package (see general submission procedures on page 563).

Deadline: December 1, 1995

\section{Samuel Lazerow Fellowship for Research in Acquisitions or Technical Services in an Academic or Research Library}

This award fosters advances in acquisitions or technical services by providing librarians a fellowship for travel or writing in those fields. Research projects in collection development or the compilation of bibliographies will not be supported by this fellowship.

Award: $\$ 1,000$ cash and a citation donated by the Institute for Scientific Information.

Criteria: The proposals will be judged with an emphasis on the following:

1. Potential significance of the project to acquisitions or technical services work.

2. Originality and creativity
3. Clarity and completeness of the proposal.

4. Evidence of an interest in scholarship, such as a previous publication record.

Submission procedure: Brief proposals (five pages or less, double-spaced) should include the following:

1. Description of research, travel, or writing project.

2. Schedule for project.

3. Estimate of expenses (e.g., professional travel, computer time, photocopying, typing.)

4. An up-to-date curriculum vitae should accompany proposal.

Recipients of the fellowship are required to submit a report on the results of their research for possible publication in CERL News.

Send eight copies of the application (see general submission procedures on page 563).

Deadline: December 1, 1995.

\section{PUBLICATIONS OR ARTICLES}

\section{Katharine Kyes Leab and Daniel J. Leab American Book Prices Current Exhibition Catalogue Awards}

These awards recognize outstanding catalogues published by American or Canadian institutions in conjunction with exhibitions of books and/ or manuscripts.

Award: A printed citation to the winning institutions organizing the exhibitions. Katharine Kyes Leab and Daniel J. Leab, American Book Prices Current, established an endowment to fund the awards.

Eligibility: Catalogues published by American or Canadian institutions in conjunction with an exhibition of books and/or manuscripts which has taken place or which is in progress before August 31, 1995, are eligible. Catalogues must be published between September 1, 1994 , and August 31, 1995. The entries will be divided into three budget categories - expensive, moderately expensive, and inexpensive-based upon the production costs as outlined in the entry form. Catalogues may be of varying formats, styles, and scope, but each must represent an exhibition which has taken place. Catalogues may be intended for various types of audiences: e.g., scholars, students, general public. Catalogues may have various purposes: e.g., publicity, dissemination of information about a collection, attraction of donations, commemoration of a special occasion, etc.

Criteria: Catalogues will be judged on the level of accuracy and consistency of presenta- 
tion, their clarity, quality of design, and usefulness to the intended audience.

Submission procedure: Four (4) copies of the catalogue must be submitted with an entry form (available from the chair of the committee) to the chair: Stephen Tabor, Clark Library, 2520 Cimarron, Los Angeles, CA 90018. All submissions will become the property of RBMS. If you have questions, call Tabor at (213) 731-8529.

Deadline: September 30, 1995.

\section{K.G. Saur Award for Best Article in College \& Research Libraries}

This recognizes the most outstanding article published in College \& Research Libraries ( $C E R L)$ during the preceding volume year.

Award: A citation and $\$ 500$ cash to each author donated by K.G. Saur

Eligibility: Articles published in CERL during the preceding volume year.

Criteria: The winning article will be selected on the basis of originality, timeliness, relevance to ACRL areas of interest and concern, and quality of writing.

Submission procedure: Articles for CERL may be submitted to the editor: Gloriana St. Clair, Assistant Dean for Access Services, E506 Pattee Library, Pennsylvania State University, University Park, PA 16802.
California, Rivera Library, P.O. Box 5900, Riverside, CA 92517.

\section{Instruction Section Publication Award}

This annual award recognizes an outstanding publication related to instruction in a library environment published in the preceding two years.

Award: A citation presented by the Instruction Section Awards Committee.

Criteria: Publications are judged on the basis of relevance to the field of instruction in academic or research libraries, originality, timeliness, and quality of writing.

Eligibility: Publications include journal articles, books, and book chapters. Submitted publications may be authored by one or more individuals, a group, organization, or committee. Instruction Section publications are not eligible for consideration for the award. Publications from 1994 and 1995 will be considered for the award to be presented at the ALA 1996 Annual Conference.

Submission procedure: Send a complete citation for the publication with the nomination letter to: Robert F. Rose (committee chair), University of Northern Iowa, Rod Library, Cedar Falls, IA 50613-3675; (319) 273-2737

Deadline: December 1, 1995.

\section{Rare Books \& Manuscripts Librarianship Award}

This award stimulates the contribution of articles of superior quality to the biannual ACRL journal Rare Books and Manuscripts Librariansbip (RBML).

Award: $\$ 1,000$ cash to an author and a citation donated by Christie, Manson \& Woods.

Eligibility: Article published in $R B M L$ during the two preceding volume years. The next award will be given in 1997.

Criteria: The winning article will be selected on the basis of significance, originality, timeliness, thoroughness, and pertinence to issues relating to the theory and practice of special collections librarianship. Other criteria will inclucle clarity of thought and expression.

Submission procedure. Articles for $R B M L$ may be submitted to the editor: Sidney Berger, University of

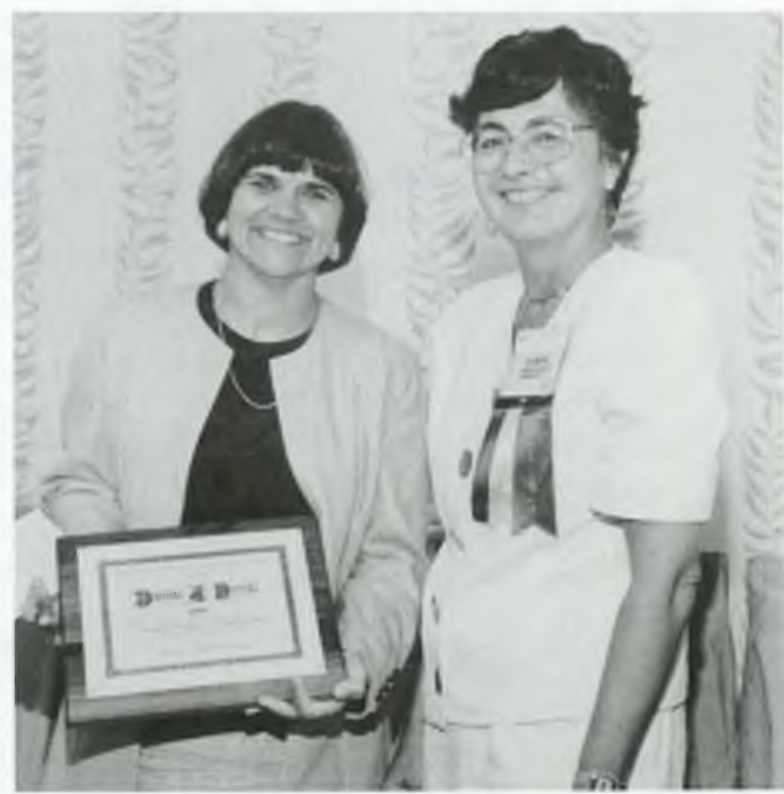

Danuta Nitecki (left) and then ACRL president Sue Martin display the 1995 ACRL/ISI Doctoral Dissertation Fellowship plaque Nitecki received. 


\section{Congressional Quarterly Books announces:}

\section{The Encyclopedia of Democracy}

Seymour Martin Lipset

Editor-in-Chief

From Johannesburg to Port-au-Prince to Tiananmen Square...

...the life-and-death conflicts around the world today vividly illustrate the powerful, enduring dream of democracy.

Now Congressional Quarterly Books, the nation's most respected government and political science publisher, introduces a groundbreaking resource detailing the fascinating evolution of democracy, from ancient times to today.

Definitive, comprehensive, and current Written at the general encyclopedia level and richly illustrated with over 200 maps, voting charts, and photographs, the Encyclopedia will include up-to-date coverage of today's events and in-depth profiles of:

- The turning points in democracy's development throughout history;

- The countries and regions where democracy has flourished and floundered;

- The leaders who have sparked democratic revolutions;

- And the concepts and philosophies that form democracy's foundation.

Call 1-800-638-1710 for a free prospectus or to order at prepublication savings; or FAX your request to 202-887-6706.

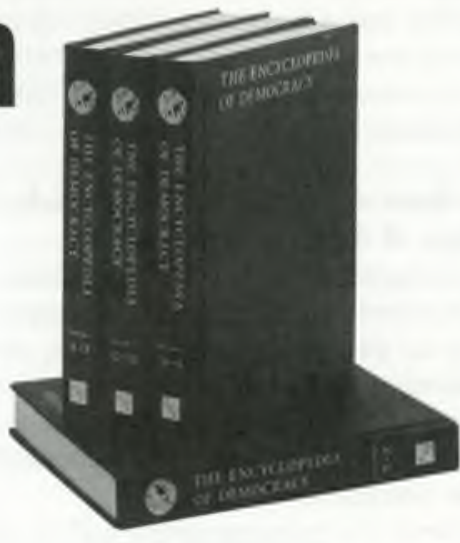

Key Features

- Four volumes

- Approximately 1,800 pages

- Alphabetically organized

- More than 400 original articles by over 200 international scholars

- Over 200 illustrations

- Time line of democracy

- Indexed and cross-referenced

- Detailed bibliographies

- 8-1/2 $\times 11^{-}$

- Handsome, durable binding

- Smyth-sewn; volumes lie flat when open

\section{Publication: 0ctober 1995} ISBN 0-87187-675-2

Price: $\$ 395$ (Canada \$495 )

Special prepublication price: \$349 (Canada \$435)

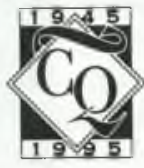

Congressional Quarterly Books

1414 22nd Street, N.W. Dept. V10

Washington, D.C. 20037 


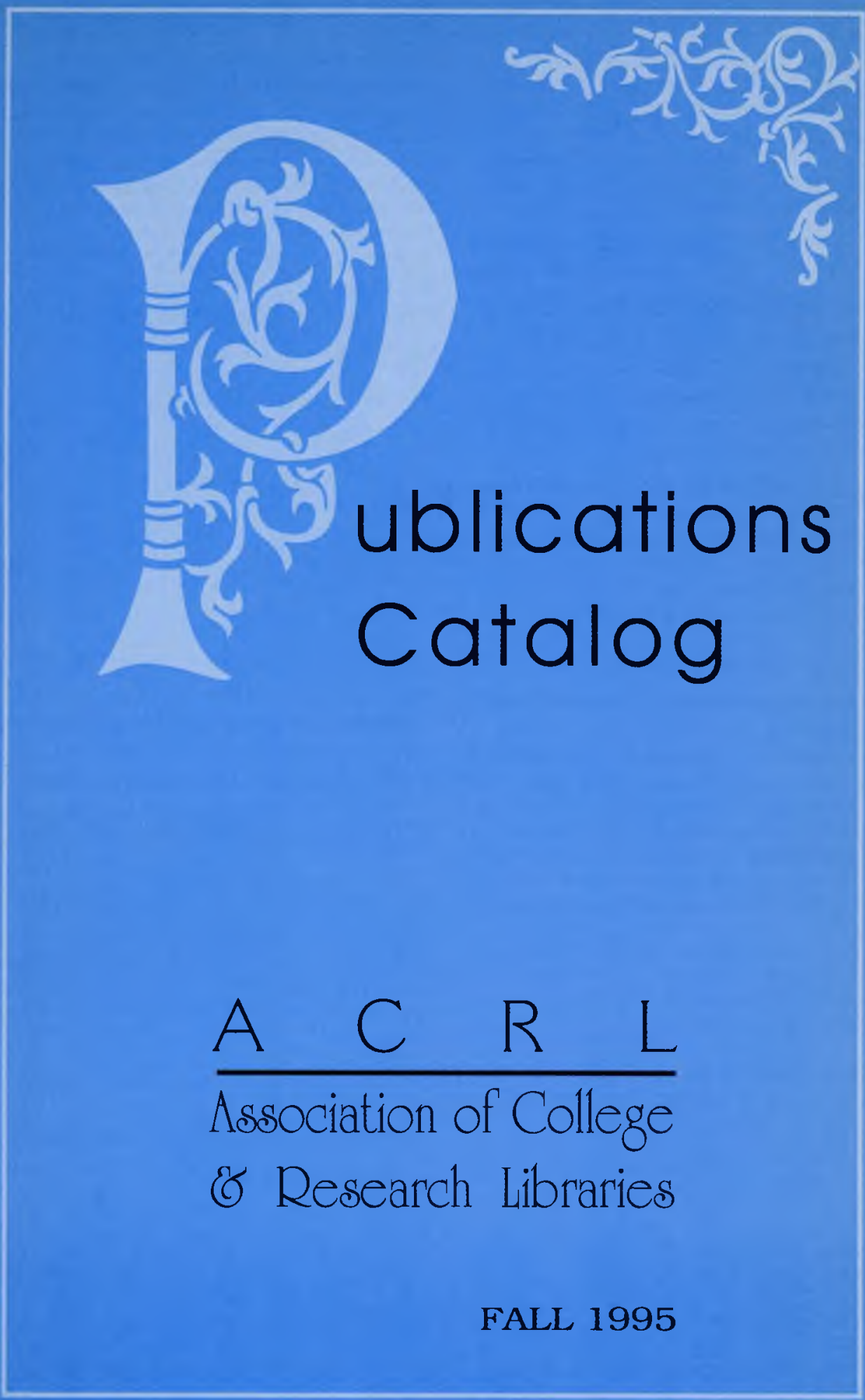




\section{Preparing for Accreditation:}

A Handbook for Academic Librarians Patricia Ann Sacks and Sara Lou Whildin

This valuable, step-by-step workbook helps librarians complete their self-study and evaluation processes.

$\$ 18.00,80 \mathrm{p}$ 0-8389-0621-4, 1993

\section{Recruiting the Academic Library Director: A Companion to the Search} Committee Handbook Sharon Rogers and Ruth Person

\$18.95; ACRL member $\$ 15.95$

0-8389-7484-8, 1991
Measuring Academic Library Performance: A Practical Approach Nancy Van House, Beth Weil, and Charles McClure

This easy-to-use set of output measures is designed to assist in measuring the impact, efficiency, and effectiveness of academic library activities

$\$ 34.00$, 140p., 0-8389-0529-3, 1990; $\$ 75.00$ with self-running databose, 0-8389-0542-0, 1991

\section{CLIP Notes}

Practical ideas for managing your library's programs and services are contained in ACRL's College Library Information Packets (CLIP Notes). Fach CLIP Note provides data and sample documents from college and small university libraries that will assist you in establishing or refining services and operations.

\section{NEW!}

\section{Allocation Formulas in Academic Libraries, CLIP Note \#22}

Jane H. Tuten, Beverly Jones, comps.

Identifies elements used in allocation

formulas and provides guidelines for college and small university libraries for implementing formulas in the budget allocation process. Includes a variety of documents representing different allocation methods, such as weighted, unweighted, and percentage-based formulas; narrative descriptions; and sample worksheets. \$23.95; ACRL member \$19.95, 90p. 0-8389-7812-6, 1995

\section{Library Services for Non- Affiliated Patrons, CLIP Nole \#21} Eugene S. Mitcbell, comp.

Sample policies and procedures for dealing with service to the non-affiliated library user. Collected from academic institutions nationally. Includes examples of information sheets, application and registration forms, ID cards, recourse letters, and reciprocal agreements.

$\$ 32.95$; ACRL member $\$ 27.95,151 \mathrm{p}$ 0-8389-7781-2, 1995
Managing Student Employees in College Libraries, CLIP Nole \#20 Michael Kathman, Jane McGurn Katbman, comps.

Comprehensive guidance for managing student employees. Includes examples of policies and procedures for employment, dismissal, orientation, training, super vision, and performance review.

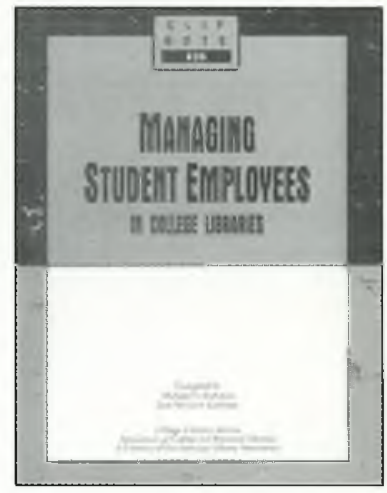

"Highly recommended for small and medium-sized libraries employing student workers."-Library Journal

$\$ 29.95$; ACRL member $\$ 25.95,140 \mathrm{p}$. 0-8389-7752-9, 1994 
Formal Planning in College

Libraries, CLIP Note \#19

Sarab Watstein, Pamela Wonsek, Paula Matthews, comps.

A survey of formal planning procedures at academic libraries. Includes examples of worksheets and checklists, vision statements, and formal planning documents $\$ 27.95$; ACRL member $\$ 24.95,120 \mathrm{p}$.

0-8389-7743-X, 1994

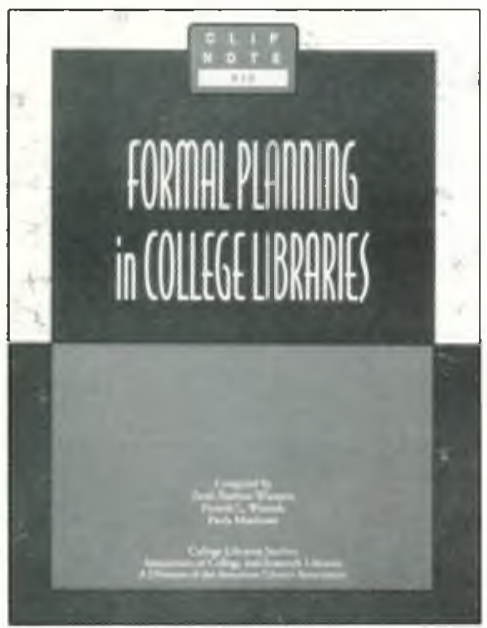

\section{Staff Development and Continu-} ing Education, CLIP Note \#18

Elizabeth Sudduth, Lynn Livingston, comps.

Survey and examples of policies for development and continuing education of both professionals and paraprofessionals. Sample documents are from development plans specifically for library personnel and from collegewide faculty development plans.

$\$ 22.95$; ACRL member $\$ 19.95,134 \mathrm{p}$ 0-8389-7715-4, 1994

\section{Emergency Planning and Man- agement in College Libraries, CLIP Note \#17}

Susan C. George, comp.

Policies and procedures for emergency planning and management in college libraries. Includes examples of plans covering everything from earthquakes to salvage procedures.

$\$ 28.95 ;$ ACRL member $\$ 25.95,146 p$.

0-8389-7710-3, 1994
Interlibrary Loan in College

Libraries, CLIP Note \#16

Roxann Bustos, comp

Sample policies and procedure statements, forms, public relations documents, and instructional handouts for libraries offering online searching, CD-ROM, and other computer-based services.

$\$ 34.50$; ACRL member $\$ 28.75,148 p$. 0-8389-7652-2, 1993

\section{Database Searching in College Libraries, CLIP Note \# 15}

Sarab Pederson, writer and comp

Samples of policies and procedures

statements, forms, promotional documents, and instructional handouts.

$\$ 29.95$; ACRL member $\$ 24.95,123 p$.

0-8389-7651-4, 1993

\section{Audiovisual Policies in College Libraries, CLIP Note \# 14 \\ Kristine Brancolini, comp.}

"The documentation included in the kit is clear and of good quality and covers all aspects of establishing and managing an audiovisual collection."-IRTS

$\$ 21.95$; ACRL member $\$ 18.95,152 p$. 0-8389-7495-3, 1991

\section{College Library Newsletters,} CLIP Note \#13

Patricia Smith Butcher and Susan McCartby Campbell, comps

Sample newsletters as well as nameplates, graphics, and style manuals/guidelines for guest editors are included.

$\$ 18.95$; ACRL member $\$ 15.95,154 \mathrm{p}$. 0-8389-7445-7, 1990

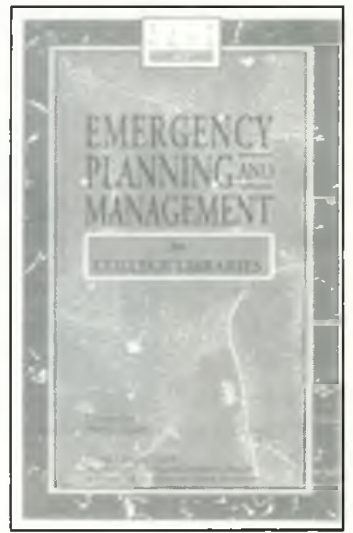




\section{Performance Appraisal in} Academic Libraries, CLIP Note \#12 Barbara Williams Jenkins, comp., with the assistance of Mary L. Smalls

". . . a wide variety of philosophies and approaches, ranging from series of relatively open-ended questions to grids for grading employees on specific qualities and achievements."-JAL

$\$ 18.95 ; \mathrm{ACRL}$ member $\$ 15.95,128 \mathrm{p}$. 0.8389-7444-9, 1990

\section{Collection Development Policies for College Libraries, CLIP Note \# 11 \\ Theresa Taborsky, comp.}

"... this volume is well worth the price." - library Journal

$\$ 26.95$; ACRL member $\$ 21.95,175 \mathrm{p}$.

0-8389-7295-0, 1989
Annual Reports for College Libraries, CLIP Note \#10 Kenneth Oberembt, comp.

$\$ 21.95$; ACRL member $\$ 18.75,135 p$. 0-8389-7219-5, 1988

\section{Friends of College Libraries,} CLIP Note \#9

Ronelle Thompson, comp.

"This is a must for two groups of libraries: those who have Friends groups and those who do not."-Library Journal

$\$ 18.75$; ACRL member $\$ 15.50,134 \mathrm{p}$. $0-8389-7171-7,1987$

\section{Periodicals in College Libraries, CLIP Note \#8}

Jamie Webster Hastreiter, Larry

Hardesty, David Henderson, comps.

"Recommended for all college and university libraries."-Library Journal

$\$ 18.75$; ACRL member $\$ 15.45,116 p$. 0.8389-7143-1, 1987

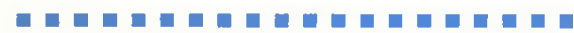

\section{PERSONNEL ISSUES}

\section{Discovering Librarians: Profiles of a Profession}

Mary Jane Scherdin, editor

Results of national studies of vocational interests of library and information professionals. The librarian profile is presented from the ACT, the Strong Interest Inventories, the Myers-Briggs Type Indicator, and the SIGI PLUS computer-aided career guidance tool, along with analysis of demographic data. Readers "will be rewarded with a better understanding of their own career choices and the need to insure that guidance counselors and guidance tools accurately reflect the current needs of our profession"-Library Journal $\$ 35.95$; ACRL member $\$ 31.95,220 p$. 0-8389-7753-7, 1994

\section{Academic Status: Statements and Resources, Second Edition}

Susan Kroll, editor

A compiliation of the ACRL standards and guidelines that apply to faculty status for academic librarians, as well as a selective bibliography.

$\$ 10.95$; ACRL member $\$ 8.95,62 \mathrm{p}$.

0-8389-7739-1, 1994 


\section{Collection Managment in the} Electronic Age: A Manual for Creating Community College Collection Development Policy Statements Jennie S. Boyarski, Kate Hickey, editors A survey of community and junior colleges collection development policies with examples of eleven complete and seven partial policy statements.

". . valuable to academic and school libraries of

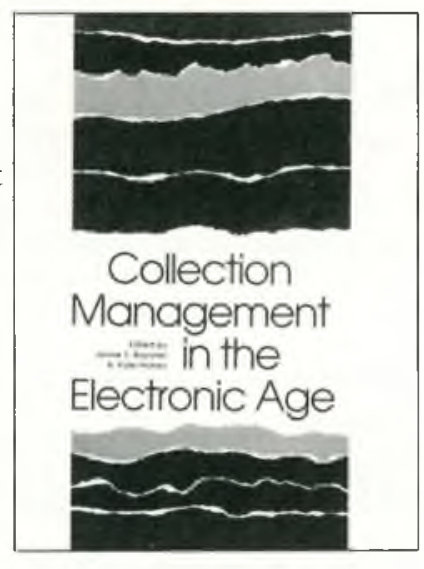
all sizes and should be read by librarians engaged in collection development ...Library Journal

$\$ 42.95$; ACRL member $\$ 35.95,197 p$. 0-8389-7737-5, 1994

\section{State Education Documents:}

A State-by-State Directory for Their Acquisition and Use EBSS Education-Related Government Publications Subcommittee

This directory provides the means to access the large variety of state education documents available from government agencies.

$\$ 21.95$; ACRL member $\$ 18.95,54 \mathrm{p}$. 0-8389-7327-2, 1989

\section{Curriculum Materials Center Collection Development Policy,} Second Edition

Beth G. Anderson, Virginia Nordstrom, Karin Duran, Allison G. Kaplan, comps.

A model policy is provided along with example policies from libraries that illustrate modifications to the model to fit specific local needs.

$\$ 16.95$; ACRL member $\$ 14.95$, 46p. 0-8389-7707-3, 1993

\section{Books for College Libraries III}

This set covers more than 50,000 titles chosen to represent a core collection of books for four-year college and university libraries. $B C I .3$ is also available on machinereadable tape. Contact ACRL. "Highly recommended."-Library Journal. $\$ 600 / 6$ vol. set, $\$ 125$ individual volume 0-8389-3353-X, 1988

\section{Directory of Curriculum Materials Center, 1990} Donald Osier, Carol Wright, Janet Lawrence, Mary Ellen Collins, Beth Anderson, comps.

This directory includes 272 institutions and covers purpose, hours, staffing, budget, service, and holdings.

$\$ 39.50$; ACRL member $\$ 32.95,240$. 0.8389-7439-2, 1991

\section{Western European Studies:}

Current Research Trends \& Library Resources

Eva Sartori, Ceres Birkhead, Jobn Cullars, John Dillon, Thomas Kilton, editors

Eleven research papers offer thoughtful synthesis, personal insight, and information useful for anyone dealing with recent scholarship in Western Furopean studies. $\$ 32.95$; ACRL member $\$ 29.95,120 \mathrm{p}$. $0-8389.7461 .9,1990$

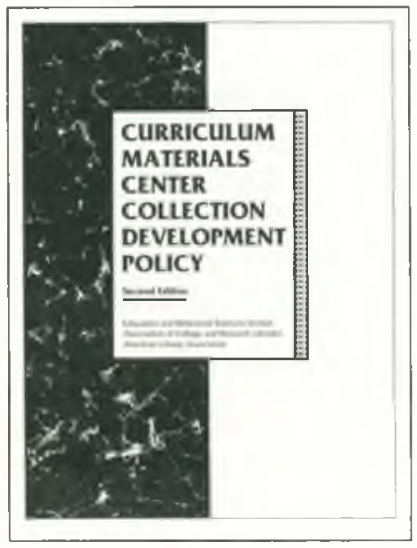




\section{Women's Studies Collection Development Policies}

The WSS Collection Development and Bibliograpby Committee

This unique tool identifies issues and provides models of existing policies. Complete policy statements from 16 university libraries illustrate the range of issues and provide a variety of models. The RLG Conspectus; Women's Studies supplemental guideline, included as an appendix, identifies issues unique to women's studies and describes materials and sources.

$\$ 35.95$; ACRL member $\$ 29.95,122 p$. $0-8389-7596-8,1992$

\section{Ethnic Studies Reviews}

Publications in this series from CIIOICE are compiled by the editors from reviews previously published in the magazine (volumes 27 through 29, Asian Americans through volume 30). Each collection provides the full text of the CHOICE review and author and title indexes. The editors consider these collections representative of the significant books that CIIOICE reviewed in these ethnic areas. Order from CHOICE, 100 Riverview Center, Middletown, CT 06457

\section{Asian and Asian American Studies}

$\$ 20.00,605$ tilles, $113 p$. $0-8389-7691-3,1993$

\section{Latino Studies}

$\$ 20.00,525$ titles, $112 p$.

0-8389-7631-X, 1992

\section{African and African American Studies}

$\$ 22.00$, approximately 750 tifles, $152 p$. 0-8389-7691-1, 1992

\section{Native American Studies}

$\$ 15.00,278$ titles, 60p.

0-8389-7632-8, 1992

\section{SPECIAL COLLECTIONS}

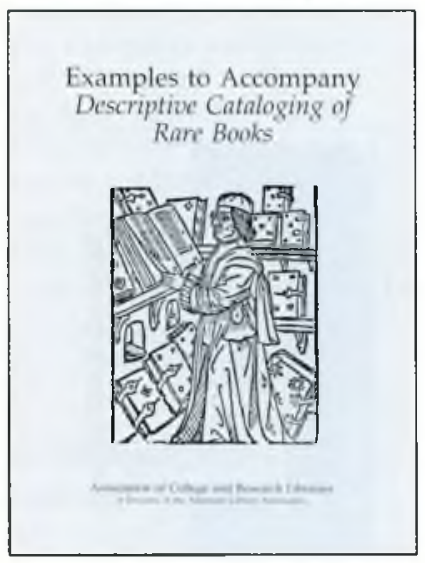

\section{Examples to Accompany Descriptive Cataloging of Rare Books}

Prepared by the Bibliographic Standards Committee of the Rare Books and Manuscripts Section

"The introduction is clear, the bibliography useful, the indexes exhaustive and the records themselves painstakingly accurate. In short, it is a model of its kind, and should be consulted not only by those cataloguers currently using the code but also all managing librarians considering its adoption."-Rare Books Newsletler $\$ 29.95$; ACRL members $\$ 23.95,148$. 0-8389-7672-7, 1993 


\section{Thesauri for Use in Rare Book and Special Collections Cataloging}

These thesauri were developed for use in MARC field 655 and 755 . Fach thesaurus provides standardized vocabulary for retrieving items by form and genre or by various physical characteristics which are typically of interest to special collections librarians.

Genre Terms (2nd ed.)

$\$ 21.95$; ACRL member $\$ 18.95,90 p$.

$0-8389-7516-X, 1991$

\section{Paper Terms}

$\$ 8.95$; ACRL member $\$ 7.50,52 \mathrm{p}$.

$0-8389-7427-9,1990$

\section{Type Evidence}

$\$ 8.95$; ACRL member $\$ 7.50,19 p$.

0-8389-7428-7, 1990

\section{Binding Terms}

$\$ 11.50$; ACRL member $\$ 9.50,37 p$.

0-8389-7210-1, 1988

\section{Printing \& Publishing Evidence}

$\$ 8.95$; ACRL member $\$ 7.50,28 p$.

0-8389-7108-3, 1986

\section{Provenance Evidence}

$\$ 10.50$; ACRL member $\$ 8.50,24 \mathrm{p}$.

0-8389-7239-X, 1988

\section{BIBLIOGRAPHIC INSTRUCTION}

\section{NEW!}

\section{Teaching Information Retrieval and Evaluation Skills to Educa- tion Students and Practitioners:}

A Casebook of Applications

Patricia O'Brien Libutti, Bonnie Gratch, editors

Scenarios depicting actual instructional sessions at the undergraduate, graduate, practitioner, and high-school level using goals and objectives statements. Several cases include the teaching of FRIC and Internet resources. Most useful are the relective analyses of the session by librarian-instructors that reveal lessons learned about teaching technology.

Price T.B.D.

0-8389-7813-4, 1995

\section{Learning to Teach: Workshops on Instruction}

Nine workshops cover the basics including clear, concise discussions of classroom techniques, new technologies, and instruction in a multicultural environment. This collection of workshops is designed to develop fundamental skills and addresses critical issues in bibliographic instruction. "Recommended for practitioners as well as academic, library school, and school library collections."-Library Journal

$\$ 24.95$; ACRL member $\$ 21.95,86 p$.

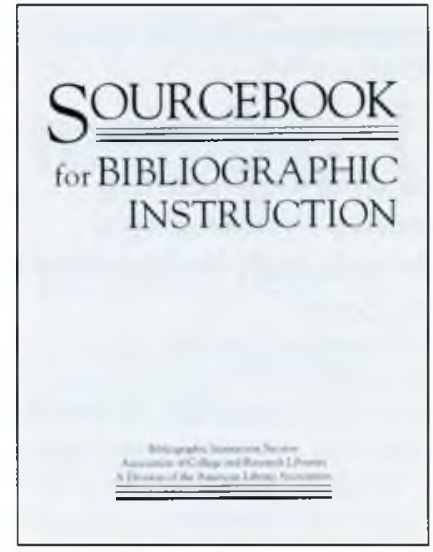

\section{Sourcebook for Bibliographic Instruction}

The Editorial Board of the Bibliographic Instruction Section

A working, desk-top tool for new and experienced bibliographic instruction librarians, the Sourcebook is practical and easy-to-use. Five essential topics are covered: learning theory, instructional design, teaching methods, evaluation, and administration. "Highly recommended for all institutions engaging in 13I."-Library Journal

$\$ 18.95$; ACRL member $\$ 16.95,96 p$. 0-8389-7673-5, 1993 
Read This First: An Owner's Guide to the New Model Statement of Objectives for Academic Bibliographic Instruction

Carolyn Dusenbury, Monica Fusich, Kathleen Kenny, and Betb Woodard, editors

"...the MSO [model statement objectives] may serve as a checklist in evaluating existing BI programs, developing educational goals when determining new programs, and determining whether such goals are being achieved."-Library Journal $\$ 19.95$; ACRL member $\$ 16.45,72 \mathrm{p}$. 0-8389-7548-8, 1991

\section{INFORMATION ACCESS}

\section{NEW! \\ Internet Resources: A Subject Guide}

Hugh A. Thompson, comp.

Ncwly updated articles originally appearing in CERL News that list information sources on the Internet, including gophers, WWW, listservs, bulletin boards, discussion groups, online bibliographies, newsletters, and more. Sixteen diverse subject areas ranging from architecture to womens' studies.

$\$ 18.00 ;$ ACRL member \$15.00, $116 p$.

0-8389-7785-5, 1995

\section{NEW!}

\section{Science and Engineering Conference Proceedings:}

A Guide to Sources for Identification and Verification

Barbara DeFelice, editor

Overview of the coverage and indexing of conference proceedings and papers in subject-oriented abstracting and indexing services. A valuable working tool for the practicing librarian involved with public services for the scientific and engineering community.

$\$ 16.50$; ACRL member $\$ 14.00,84 \mathrm{p}$. 0-8389-7790-1, 1995

\section{Guide to Searching the Bibliographic Utilities for Conference Proceedings}

Nirmala S. Bangalore, Judith A. Carter, editors

A convenient guide detailing search strategies for finding conference proceedings in either RLIN, OCLC/PRISM, or WLN utilities

$\$ 7.95$; ACRL member $\$ 6.95,15 p$.

0-8389-7734-0, 1994

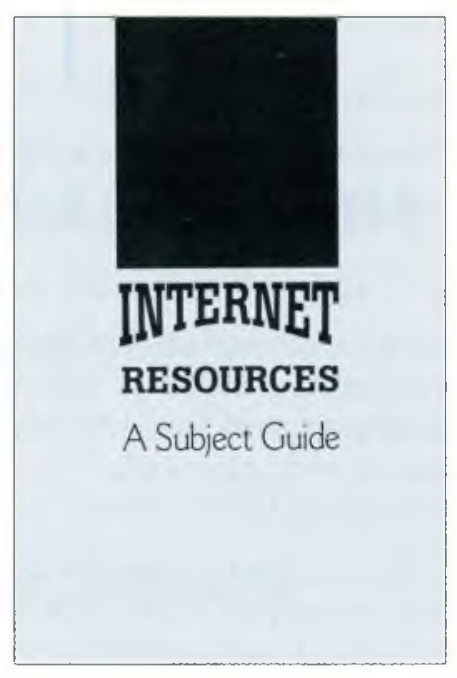

\section{Abstracting, Information} Retrieval, and the Humanities:

Providing Access to Historical Literature Publications in Librarianship: No. 48 An examination of the qualities and functions of abstracts and the challenges involved in text condensation. Helen R. Tibbo

$\$ 35.00,276 \mathrm{p}$. 0-8389-3430-7, 1993 
Vocational and Technical

Resources for Community

\section{College Libraries}

Mary Ann Laun, editor

Annotated bibliographies presenting a col-

lection of resources, both print and

nonprint, that are needed to support a vo-

cational and technical curriculum for a

community college, or a vocational or tech-

nical institution. Useful to undergraduate

students, vocational and technical students,

librarians, faculty, and the general public

looking for information on these programs'

resources. "This will become a standard

selection tool for libraries in community

college, technical institutes, and vocational-

technical high schools. .. four-year-col-

lege, libraries and medium-size and large

public libraries... should consider it for

their reference collections."-Booklist

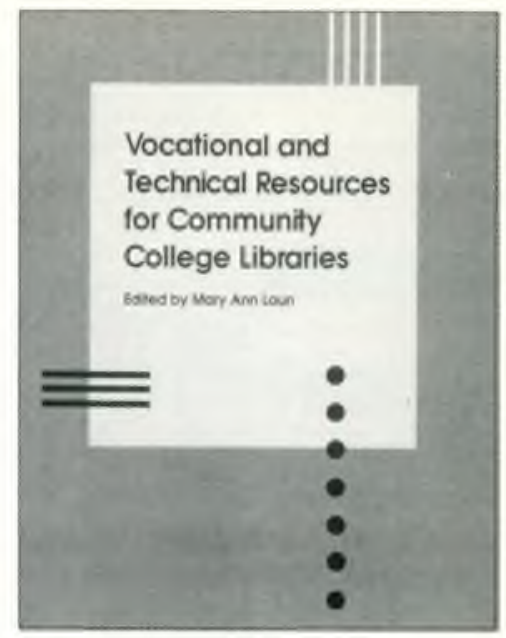

$\$ 95.00$, ACRL member $\$ 85.00,622 p$.

$0.8389-7775-8,1995$

\section{Recruit a new member !}

\section{There's strength in numbers.}

Sign up new members and we all benefit.

Get the word out about the advantages of ACRL membership.

\footnotetext{
* Career information resources

* Awards and fellowships

* Publications

* Electronic communications

* Continuing professional development
}

* Discussion groups
* Advocacy
* Sections
* Chapters
* Standards and
Guidelines

\section{Help $\mathbf{G C R} \mathbf{L}$ grow!}

Call Noreen Hale (312/280-2510) at

ACRL for membership materials. 


\section{STATISTICS \& RESEARCH}

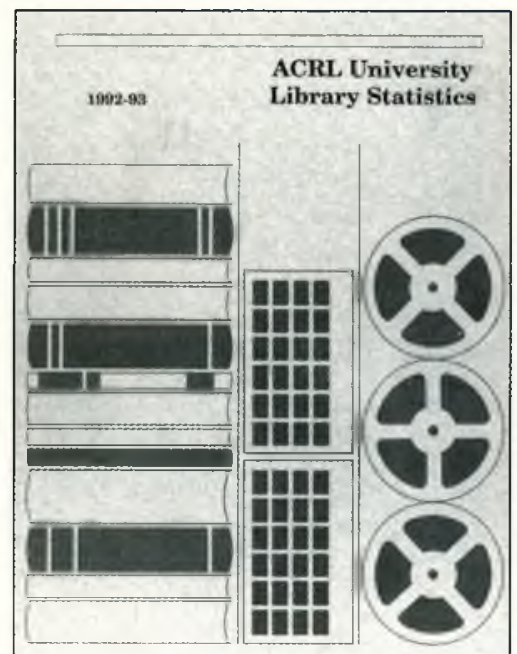

\section{NEW}

\section{Continuity and Transformation:} The Promise of Confluence

Proceedings of the Seventh National Conference of the Association of College and Research Libraries Richard AmRbein, editor

Describes how librarians across the country are incorporating new and established technologies to enhance the teaching, learning, and research processes. Includes 54 refereed contributed papers and abstracts of 31 panel sessions.

$\$ 49.95$; ACRL member $\$ 44.95,500 \mathrm{p}$. 0-8389-7786-3, 1995

\section{Academic Libraries Achieving Excellence in Higher Education:}

Proceedings of the Sixth National Conference of the Association of College and Research Libraries Thomas Kirk, editor

Practical examinations and solutions to current academic library problems are included in 4 keynote addresses, 36 program reports, and 52 refereed contributed papers. "....an excellent professional development resource for librarians trying to keep current and for new librarians concerned about the profession." - JAI $\$ 49.95$; ACRL member $\$ 44.95,522 \mathrm{p}$. 0-8389-7622-0, 1992

\section{ACRL University Library} Statistics, 1992-93

Library Research Center, Graduate School of Library \& Information Science, University of Illinois at Urbana Champaign, comp.

1)ata from over 109 participating libraries. Library categories include collections, personnel, expenditures, and interlibrary loan. Institutional categories include degrees offered, enrollment size, and faculty size.

$\$ 69.95$; ACRL member $\$ 39.95,80 \mathrm{p}$. 0-8389-7738-3, 1994

\section{ACRL University Library Statistics, 1990-91}

Library Research Center, Graduate School of Library \& Information Science, University of Illinois at UrbanaChampaign, comp.

$\$ 69.95$; ACRL member $\$ 39.95,80 p$. 0-8389-7587-9, 1992

\section{ACRL/Historically Black Colleges \& Universities} Library Statistics, 1988-89 Robert E. Molyneux, comp.

$\$ 35.95$; ACRL member $\$ 25.95,101 \mathrm{p}$. 0-8389-7547-X, 1991

\section{ACRL University Library Statistics, 1988-89 \\ Denise Bedford, comp. \\ $\$ 49.95$; ACRL member $\$ 29.95,79 \mathrm{p}$. 0-8389-7446-5, 1990}

\section{ACRL University Library Statistics, 1987-88 \\ Robert E. Molyneux, comp. $\$ 49.95$; ACRL member $\$ 29.95$, 79p. $0-8389-7288-8,1989$}

\section{ACRL Academic Library} Statistics, 1978/79-1987/88

(Diskettes)

$\$ 59.95$; ACRL member $\$ 49.95$

0-8389-7310-8, 1989 


\section{ORDER FORM}

\section{Fill in your shipping and billing addresses.}

Ship to:

\section{Indicate quantity of each item you wish to order.}

Abstracting, Info. Retrieval, \$35.00; 0-8389-3430-7

Academic Lib. Achieving Excellence, $\$ 49.95 / 44.95 ; 0-8389-7622-0$

Academic Status, $\$ 10.95 / \$ 8.95$;

0-8389-7739-1

ACRL Stats 92/93, \$69.95/39.95;

0-8389-7738-3

ACRL Stats 90/91, $\$ 69.95 / 39.95$;

0-8389-7587.9

ACRL Stats 1988/89, \$49.95/29.95;

0-8389-7446-5

ACRL Stats 1987/88, \$49,95/2995;

$0-8389-7288-8$

ACRL Stats 78/79-87/88 (Diskettes),

$\$ 59.95 / 49.95 ; 0-8389-7310-8$

Allocation Formulas, $\$ 23.95 / 19.95$;

$0-8389-7812-6$

Annual Reports, \$21.95/18.75;

0-8389-7219-5

A-V Policies, \$21.95/18.95;

0-8389-7495-3

Binding Terms, \$1 1.50/9.50;

0-8389-7210-1

Books for College Libraries, $\$ 600$;

0-8389-3353-X

Collection Devel. Policies, \$26.95/

$21.95 ; 0-8389-7295-0$

Collect. Mgt. in Elect. Age, \$42.95/

$35.95 ; 0.8389 .7737 .5$

College Lib. Newsletters, \$18.95/

$15.95 ; 0-8389-7445.7$

C\&RL and C\&RL News, Index v. 41-50,

$\$ 29.95 / 25.95 ; 0.8389 .7487 .2$

Continuity \& Trans., \$49.95/44.95;

0-8389-7786-3

Curriculum Mat'ls Ctr. Dev., \$16.95/

14.95; 0-8389-7707.3
Bill to:

Database Searching in College Libraries, $\$ 29.95 / 24.95 ; 0.8389 .7651 .4$ Dir. of Curriculum Center, $\$ 39.50 /$ $32.95 ; 0.8389 .7439 .2$

Discovering librarians, $\$ 35.95$ /

$\$ 31.95 ; 0-8389-7753-7$

Emergency Planning, \$28.95/25.95;

0-8389-7710-3

Examples to Accompany DCRB,

$\$ 29.95 / 23.95 ; 0-8389.7672 .7$

Friends of College Lib., \$18.75/15.50; 0.8389-7171.7

ormal Planning, $\$ 27.95 / \$ 24.95$;

$0.8389-7743-X$

Genre Terms, \$21.95/18.95;

0.8389-7516-X

Guide to Searching, $\$ 7.95 / \$ 6.95$;

0.8389-7734-0

HBCU Stats $88 / 89, \$ 35,95 / 25.95$;

0-8389-7547-X

Info. Retrieval \& Eval. Skills,Price T.B.D.;

0.8389.7813.4

Interlibrary Loan in College Libraries,

$\$ 34.50 / 28.75 ; 0.8389-7652.2$

Internet Resources, $\$ 18.00 / 15.00$;

0.8389 .7785 .5

Learning to Teach, $\$ 24.95 / 21.95$;

0-8389-7627-1

Library Srves for Non-Affil. Patrons,

$\$ 32.95 / 27.95 ; 0.8389 .7781 .2$

Managing Student Employees, \$29.95/ $\$ 25.95 ; 0.8389 .7752 .9$

Measuring Acad. Lib. Perf., \$34.00; 0.8389.0529.3

Measuring... (disk \& book), \$75.00; 0.8389.0542.0

Paper Terms, \$8.95/7.50;

0.8389-7427.9 
Performance Appraisal, \$18.95/15.95: 0.8389-7444-9

Periodicals in College Lib., \$18.75/

$15.45 ; 0-8389-7143-1$

Preparing for Accreditation, \$18.00;

0.8389 .0621 .4

Printing \& Pub. Evidence, \$8.95/7.50;

0-8389-7108.3

Provenance Evidence, $\$ 10.50 / 8.50$; 0 8389.7239-X

Read This First, \$19.75/16.45;

0.8389 .7548 .8

Recruting Acad. Lib. Dir., \$18.95/

$15.95 ; 0.8389-7484-8$

Scholarly Communication, $\$ 28.95$ /

$24.95 ; 0.8389 .7686-7$

\section{Indicate a subtotal and add appropri- ate handling charges. Handling charges are $\$ 3.75$ for orders up to $\$ 19.99 ; \$ 4.75$ for $\$ 20$ to $\$ 49.99 ; \$ 6.50$ for $\$ 50$ to $\$ 74.99 ; \$ 7.50$ for $\$ 75$ to $\$ 149.99$; and $5 \%$ of total for orders above $\$ 150$. \\ s Subtotal \\ $\$$ Handling charges \\ $\$$ Total}

Sci./Eng'g Conf. Proc., \$16.50/

$14.00 ; 0.8389-7790-1$

Sourcebook for B.I., \$18.95/16.95: 0.8389.7673-5

Staff Development, $\$ 22.95 / \$ 19.95$; 0-8389.7715-4

State Education Doc., \$21.95/18.95: 0-8389.7327.2

Type Evidence, \$8.95/7.50;

0.8389.7428.7

Vocational Technical Resources. $\$ 95.00 / 85.00 ; 0.8389 .7775 .8$

Western European Studies، $\$ 32.95 /$

$29.95 ; 0.8389 .7461 .9$

Women's Studies Coll. Dev. Policies. $\$ 35.95 / 29.95 ; 0.8389 .7596-8$

\section{3a. Sign me up for ACRL Approval Plan:}

$\mathbf{P}$ (send all new ACRL publications)

PC (send all new CLIP Notes only)

\section{Select method of payment.}

$\square$ Check/money order enclosed Send invoice (term 30 days)

Charge my credit card: $\square$ MasterCard

$\square$ VISA American Express

Card Number: Expires:

Signature

\section{Mail order to:}

ACRL, Attention: Hugh Thompson, 50 East Huron Street, Chicago, IL 60611. For faster, more personal service, call toll-free (800) 545-2433, press 7, or fax (312) 836-9958.

Terms of Business. Institutions and individuals may order on account, plus postage and handling Prepayment should accompany individuals' orders of $\$ 30$ or less. Shipping and handling charges will be added to all orders. All prices are payable in U.S. funds, net 30 days. First price is list price.

Discounts. ALA personal and organizational members are eligible to receive a ten percent (10\%) discount on ACRL, materials (except subscription items). To receive the discount, give your membership number. and deduct the discount when preparing your orders. ACRL personal and organizational members receive 10-30\% discount on nonsubscription ACRL materials. Look for the ACRL member price in this booklet. 


\section{OFFICIAL ACRL DOCUMENTS}

Indicate quantity of each item to be shipped.

\section{ACCESS}

Guidelines for the Preparation of Policies on Library Access

CERL News, Dec. 1992. 10p. \$2.00

ALA-SAA Joint Statement on Access to Original Research Materials

CERL News, Dec. 1993, 2p. \$2.00

\section{AUDIOVISUAL}

Guidelines for Audiovisual Services in Academic Libraries CERL. News, Oct. 1987. 4p. $\$ 2.00$

\section{BIBLIOGRAPHIC INSTRUCTION}

Guidelines for Bibliographic Instruction in Academic Libraries CERL News, April 1977. 1p. \$2.00

Model Statement of Objectives for Academic Bibliographic Instruction CERL. News, May 1987. 6p. $\$ 2.00$

\section{COLLEGES \& UNIVERSITIES}

Guidelines for Branch Libraries in Colleges and Universities CERL News, March 1991 4p. \$2.00

Guidelines for Extended Campus Library Services

CERL News, April 1990. 3p, \$2.00

(also see CERL. Neus Jan. 1993 p.7 for corrections)

The Mission of an Undergraduate Library: Model Statement CERI. News, Oct. 1987. 3p. \$2.00

Standards for College Libraries CERI. News, April 1995. 12p. One copy free; additional copies $\$ 2.00$ each.
Standards for University Libraries CERL. Neus, Sept. 1989. ACRL/ARL. 13p. Single copy free; additional copies $\$ 2.00$ each.

\section{COMMUNITY \& JUNIOR COLLEGES}

Standards for Community, Junior and Technical College Learning Resources Programs. ACRL/AECT. CERL News, October 1994. 14p. Single copy free; additional copies $\$ 2.00$ each.

\section{PERSONNEL ISSUES \& FACULTY STATUS}

Guidelines for Academic Status for College and University Libraries CERL News, March 1990. 2p. \$2.00

Joint Statement on Faculty Status of College and University Librarians. ACRL/AAUP/AAC. CERL News, Feb. 1974. 1p. $\$ 2,00$

Model Statement for the Screening \& Appointment of Academic Librarians Using a Search Committee

CERL Neus, Nov. 1992. 4p. \$2.00

Model Statement of Criteria and Procedures for Appointment, Promotion in Academic Rank, and Tenure for College and University Librarians CERL. News, May 1987. 8p. $\$ 2.00$

Standards for Faculty Status for College and University Librarians CERL News, May 1992. 2p. $\$ 2.00$

Guideline on Collective Bargaining

CERL News, March 1993. 1p. \$2,00

Statement on the Terminal Professional Degree for Academic Librarians

CERL News, Jan. 1975. 1p. \$2.00 
Statement on the Certification \& Licensing of Academic Librarians CERL News, Nov. 1989. 1p. $\$ 2.00$

\section{RARE BOOKS, MANUSCRIPTS \& ARCHIVES}

Guidelines for Borrowing Special Collections Materials for Exhibition

CERL News, May 1990. 3p. $\$ 2.00$

Guidelines for the Loan of Rare and Unique Materials

CERL News, May 1993. 3p. $\$ 2.00$

Guidelines for the Security of Rare Books, Manuscripts, and Other Special Collections CERL News, March 1990. 5p. $\$ 2.00$
Guidelines on the Selection of General Collection Materials for Transfer to Special Collections, 2nd edition

CERL News, Dec. 1993. 4p, $\$ 2.00$

Guidelines Regarding Thefts in Libraries

CERI. News, November 1994. 6p. $\$ 2.00$

Relator Terms for Rare Book, Manuscript, and Special Collections Libraries

CERL News, Oct, 1987, 5p, $\$ 2,00$

Standards for Ethical Conduct for Rare Book, Manuscript, and Special Collection Librarians, with Guidelines for Institutional Practice in Support of the Standards, 2nd edition

CERL News, April 1993. 9p. \$2.00

\section{Shipping address:}

Name:

Address:

\section{Mail order to:}

ACRL Official Documents

50 Fast Huron Street

Chicago, IL 60611-2795

or FAX: $312 / 280-2520$

Recent standards have been made available on the ALA/ACRL gopher. Gopher to "gopher.uic.edu, port 70".

Items on pages 13 and 14 may be photocopied for noncommercial purposes. 


\section{Choice}

Book review journal of the Association of College and Research Libraries (ACRL).

Eleven issues per year (July/August combined)

Available by subscription only, $\$ 165 /$ year domestic rate; $\$ 187 /$ year foreign rate; single issues $\$ 20.00$ ISSN: 0009-4978.

Also available as:

\section{Choice-Reviews-on-Cards}

Reviews from each monthly issue of choice printed on $3 \times 5$ cards.

Available to Choice subscribers only for $\$ 245$ / year domestic rate; $\$ 265$ /year foreign rate; sample box $\$ 25.00$. Order either Choice product from: Circulation Deparment, Choice, 100 Riverview Center, Middletown, CT 06457 (203) 347-6933.

\section{Rare Books \& Manuscripts Librarianship}

A journal of theory and practice covering all aspects of special collections librarianship. Two issues/year.

$\$ 30.00$ U.S.; $\$ 35.00$ for Canada and Mexico; and all other countries $\$ 40.00$; single issues $\$ 15.00$ each. ISSN: 0884-450X.

\section{College \& Research Libraries}

Official journal of the Association of College and Research Libraries. Six bimonthly issues per year. Sent to ACRL members as a perquisite of membership. Also available on subscription. $\$ 50.00$ per year in the U.S.; Canada and Mexico $\$ 55.00$ per year; and all other countries $\$ 60.00$; single issues $\$ 14.00$ each. ISSN: 0010-0870.

\section{College \& Research Libraries News}

Official news magazine of the Association of College and Research Libraries. Fleven issues per year (July/August combined). Sent to ACRL members as perquisite of membership. Also available on subscription.

$\$ 35.00$ per year in the U.S.; $\$ 40.00$ per year in Canada and other PUAS countries; $\$ 45.00$ in other foreign countries; single issues $\$ 6.50$ each. ISSN: 0099-0086.

\section{College \& Research Libraries and College \& Research Libraries News, Index for Volumes 41-50 (1980-89) $\$ 29.95$; ACRL member $\$ 25.95,180$ p. 0-8389-7487-2, 1991}

\section{ACRL APPROVAL PLANS}

ACRL publications provide practical ideas, tools, and methods for: management, biloliographic instruction, special collections, collection development, statistics, and research. The convenient and cost-cutting ACRL approval order plan provides automatic priority shipping of ACRL's new books at a $20 \%$ discount to ACRL members ( $10 \%$ to nonmembers).

There are two approval plan categories from which to choose:

- Plan P guarantees that you will automatically be sent all new ACRL publications including CLIP Notes. ACRL publishes approximately 5 to 6 new titles each year.

- Plan PC is exclusively for titles in the CLIP Notes (College Library Information Packets) series. CLIP Notes collect data and sample documents from academic libraries to assist librarians in establishing or refining services and operations

It's easy to enroll. Make your selection on the order form in this catalog. Or call or write the ACRL Publications Officer indicating the category you have chosen. ACRL/ALA, Approval Plan, 50 Fast Huron Street, Chicago, IL 60611; (800) 545-2433, ext. 2517 
